\title{
Improving Student's Reading Comprehension Ability Using Jigsaw 1 Technique
}

\author{
Caroline V. Katemba \& Samuel \\ Correspondence author Caroline (linakatemba@gmail.com) \\ Universitas Advent Indonesia \\ DOI: https://doi.org/10.35974/acuity.v2i2.613
}

Name of Journal

Acuity: Journal of English Language Pedagogy, Literature and Culture, Vol 2 No 2 (2017).

PUBLISHED: 2017-08-01 URL https://jurnal.unai.edu/index.php/acuity/article/view/613

\begin{abstract}
This research is entitled "Effectiveness of Utilizing Jigsaw 1 towards Improving Students' Reading Comprehension Ability. Experimental design was used in this study. The participants of this study were two classes of grade 8 of junior high school in Parongpong, Bandung, Indonesia ; each class consisted of 32 participants in grade $8 \mathrm{~A}$ as the experimental group and 33 participants in grade 8B as the control group. The Experimental group was taught using Jigsaw 1 Technique and the control group was taught using conventional technique. This study intended to seek answer on the question; Is there any significant difference on the effect of reading comprehension between those students who are using jigsaw-1 and those who are taught through conventional method. This research was divided into three steps: giving a pretest, treatment (Jigsaw 1 Technique) and the last giving post-test. Data analysis shows that, there is a significant difference in the reading comprehension ability between those who were taught using Jigsaw 1 technique and those who were taught using conventional technique.
\end{abstract}

\section{Keywords: Jigsaw 1, Reading Comprehension}

\section{Introduction}

Reading is necessary when students further their study, especially at the secondary level. They need good reading skills for acquiring knowledge and learning new information. However, the researcher can see that many students' reading abilities in Indonesia are having difficulties in understanding the text. Reading difficulties become a problem when reader cannot absorb the meaning from a text. "Indonesian students have already encountered problems with reading comprehension in Indonesian, the language that they've acquired and learned, they also find it way more difficult to read and comprehend reading in English, the foreign language that they do not acquire and learn it barely for a short time" (Siagian \& Katemba, 2016)

Understanding Syntax (Aarts, 2008). Children with reading problems often experience confusion in understanding grammars, especially if at the same time they use two or more languages have different grammar. They have problems with language both when setting the language grammar is different than the first. For example, the Indonesian-known arrangement Explain-Explained (example: bag red), but in English known as Explained-Explaining arrangement (example: red bag). To solve the difficulty in reading comprehension, learning using Jigsaw 1 technique has examined in the United State that it will give chance to students 
to share and talking to peers instead of teachers, moreover students will receive bilingual support from other friends in that group while they are talking (Edmonds et al, 2006).

Fuch et al (2001) stated that in elementary and high school, most of the students have low willingness to read in reading any text, reading for pleasure, more over reading ability is one of the goals of learning to read. But for some students, they were not care and not really giving attention. Additionally, students with low reading ability were the students who have low motivation themselves. That is why all activities in the classroom involving reading have a contrary attitude toward students' reading comprehension.

Guthrie (2008), stated that in teaching students that have low motivation, teacher may be spend their time to teach those students. To handle this problem, teacher who work in that problem, teachers should use strategies to encourage motivation to read. Teacher may use Jigsaw 1 method. This may help them and make student success, as well as they will have good relationships with their peer. By having good relationships, in Jigsaw 1 technique they can express their idea or opinion.

Bolukbas et al. (2011) stated that the teachers of English Language try to solve the problem by using jigsaw 1 technique. This is a way for the researcher to improve the students reading comprehension. Jigsaw 1 technique is one of several cooperatives learning techniques. It is a way to teach students to be smart in learning material. In this research, the Jigsaw 1 technique was used to teach English reading comprehension. Even though there are many techniques used in teaching English reading, the writer chose Jigsaw 1 technique to improve the students' reading comprehension because the Jigsaw 1 technique helps students communicate with one another if they have problems in reading the text. Usually students face many problems in reading text. For example: difficult words, comprehension of sentences, how to read the word or sentence correctly, and etc.

In reading class, most of the reading activities are focused on reading for comprehension. As argued by Richard and Renandya (2002), reading for comprehension is the primary purpose for reading. Therefore, students are usually expected by their teachers to comprehend reading texts. Students are expected to be smart readers who are able to effectively comprehend the text.

Cooperative learning is one of the most popular methods of improving reading comprehension. It has been shown to positively effect various outcomes (Johnson \& Johnson, 2002). Cooperative learning is a teaching method by which learner study by helping one another in small groups during the learning process in order to achieve a common objective (Stevens, 2003). Cooperative learning as a concept consists of several instructional methods in which learners study a language in small groups of four to six persons and group performance in several different ways (Slavin, 2004).

According to Suprijono (2009) adopted by Dewi Nurcahyanti research is "The Implementation of Jigsaw Method To Improve Students' Reading Comprehension at SMPN 2 Jetis Deponorogo" stated that there is another method of teaching, which is interesting, and can improve student's reading comprehension, namely Jigsaw 1 technique. Jigsaw 1 technique is one method that is very simple to apply and can increase enjoyment of the learning process. Jigsaw is the appropriate method which demands the students on 4-6 groups, the name of home teams. Jigsaw 1 technique is one of the appropriate methods that can be used in teaching reading because jigsaw 1 technique is cooperative learning method to promote better learning, improve students' motivation, and increase enjoyment of the learning process.

Ceyhun Ozan (2009) in research's title "The Effect of the Jigsaw 1 Technique Implementation on Prospective Teachers' Academic Achievements" at Public University in 
Turkey, the Jigsaw 1 method is more successful in group learning. Every student in the group share knowledge in every part of the course. Also, students in each group should feel responsible for the success of the other members.

\section{Statement of the Problem}

The purpose of this research was to discover whether Jigsaw 1 technique is effective in improving students reading comprehension ability at SMPN 3 Parongpong Bandung. Therefore, the research sought to answer the following question: Is there any significance difference in reading comprehension ability between those who were taught using the Jigsaw 1 technique and those who were taught using conventional technique?

\section{Hypothesis}

The researcher hypothesized that teaching English through Jigsaw 1 technique would positively correlate with and improve the students' reading comprehension ability. It was expected that progress of students who were taught reading comprehension through Jigsaw 1 technique would be reflected in their scores on the achievement test. Furthermore, the results of the studies would be summarized in one of the following conclusions:

Ho: There is no significant difference in reading comprehension ability between those who were taught Jigsaw 1 technique and those who were taught conventional technique.

Ha: There is a significant difference in reading comprehension ability between those who were taught jigsaw 1 technique and those who were taught conventional technique.

Jigsaw technique

The Jigsaw technique was the method used by the researcher in this study. This section discusses Jigsaw 1 technique as follows: definition, advantage and disadvantage.

Cooperative learning or the group work approach has several activities in the teaching learning process. Jigsaw is one method of cooperative learning in reading. Jerome Baker (2012) stated that, Jigsaw reading can be used with almost any topic. The reading can be short articles, long articles, chapters (or even entire books) with different sections that can be divided among the students.

Slavin in Novianto (2012) said that Jigsaw includes a procedure whereby students share information they have gathered with their group mates with the other group mate in the class. Students are quizzed on all topics and the quiz scores are averaged to form team scores. So, if the team wants to be successful, the team members must not only accomplish their subtasks but also do a good job of sharing information with their teammates.

According to Webb \& Culian (1994), the jigsaw approach may help build a classroom as a community of learners where they are all valued. Teaching reading will be easier because this way encourages the students to be active in the class. They will be on a team consisting of both good students and poor students. Every team consists of five or six students who will study together for better achievement in the form of individual improvement scores after taking the individual quiz. Every member in the team should be responsible for her/his own material to the member of his/her own team. 
Maria brisk and Margaret M. Harrington in Anonymous' research (2011) defined the jigsaw approach is a way for students to work cooperatively and help each other to learn new material. Students take an active role their learning as they teach other students what they have learned". As a cooperative learning method, jigsaw has to consist of group member about five to six students in one group.

Mauludi (2011), in Jigsaw technique, the students have the opportunity to improve their responsibility to their learning and they can cooperate with the other students to learn the material. Jigsaw technique is used to improve students' responsibility to their learning. The students not only study the given material, but also they must give and teach the material to the other members. So the students will depend on the other students. They must cooperate to learn the given material.

Mengduo and Xioaling (2010) stated that the jigsaw technique that was originally developed by Elliot Aronson in 1971, was considered effective in increasing positive educational outcomes. As a cooperative learning technique, it has been widely studied abroad and has been explored in various ways by a number of researchers and teachers in classes of different levels and of different subjects.

The design of the conceptual framework is outlined as follows:

Figure 1

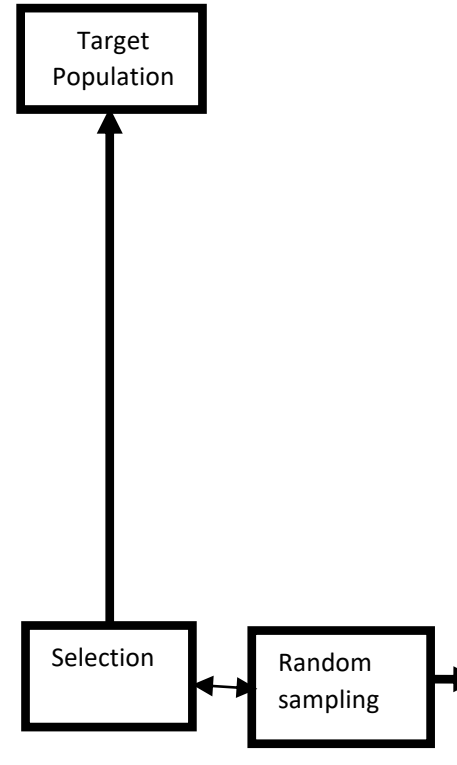

Grade 8A

experiment

al class
Treatment

(1) Divided students into 5-6 persons jigsaw groups. The groups should be not diverse in terms of gender and race,

(2) Appointed one student from each group as the leader. Initially, this person should be the most mature student in the group,

(3) Divided the days' lesson into 5-6 segments. For example, if the teacher want to ask to the students to write a topic, the teacher might divide the topic into stand alone topic on: (a). A The Blow Dryer, (b) The Heart, (c) Trees, (d) Green Grass, (e) Taste,

(4) The teacher assigned each student to learn one segment, making sure students have direct access only their segment,

(5) The teacher gave students time to read the topic at least twice and become familiar with the topic,

(6) The teacher fromed temporary "expert group" by having one student from each jigsaw group join other students assigned to the same segment. Give students to the expert groups' time to discuss the main point of their segment and to rehearse the presentation they will make to their jigsaw group,

(7) Brought the students back into their jigsaw group,

(8) Asked each student to present her or his segment to the group and encouraged others in the groups to ask questions for clarification,

(9) The teacher floated the group, observed the process, if any group is having trouble, (e.g., a member is dominating or disruptive), make an appropriate intervention. Eventually, its best for the group leader to handle task. Leaders can be trained by whispering an instruction on how to intervene, until the leader gets the hang of it,

(10) At the end of the session, the teacher gave a quiz on the material so that students quickly come to realize that these sessions are not just fun and game but really count. 


\section{Research Methodology}

Research Design

This study used experimental design in order to see whether Jigsaw 1 technique give significant positive effect in reading comprehension ability.

Table 3.1.

The Design of Research

\begin{tabular}{|l|l|l|l|}
\hline Group & Pretest & Treatment & Post-test \\
\hline Experimental & O & X & O \\
\hline Control & O & - & O \\
\hline
\end{tabular}

Where: $\quad \mathrm{O}$ : Pre-Test and Post-Test

$\mathrm{X}$ : Implementation by using Jigsaw 1 technique.

(Arikunto , 2013)

Participants

The participants of the study were Grade 8 or $2^{\text {nd }}$ year junior high school. 32 students of Grade 8A were the experimental group and 33 students of Grade 8B as the control group. Their ages range from 13 to 15 years old with 35 males and 30 females.

Research Instrument

Data collection

The study lasted for approximately 32 hours start from 23 September 2014 to 31 November 2014. The first step in gathering the data, all the participants took a pre-test, and the data for pre-test were recorded. Afterward, the participants were taught through Jigsaw 1 teaching method in English class for two an a half months with the expectation that the participants would improve in their reading comprehension skill. After the treatment was given, the post-test was administered to the participants to see the effect of the Jigsaw 1 method. In gathering the data, the researcher did the following procedure:

Testing Procedure

Pilot Test

Before giving the treatments, the researcher conducted a pilot test consist of 60 questions to measure the validity and reliability of the instrument. The pilot test was conducted in another class which did not involve the Experimental group and control group. The pilot test was conducted on Friday, September $15^{\text {th }} 2014$ in class IXA.

From the Pilot Test data, the researcher did validity test, reliability test, difficulties test, and discrimination index. 
Analysis of the Validity test

Validity test was used to measure whether the instrument is valid or invalid. The Pilot test should be tested to measure its validity and reliability before conducting pre-test and post-test.

According Anderson as quoted by Arikunto (2013) stated that a test is valid if it measures what it means to measure. To find the validity of a test item, the researcher used the formula as

follows:

$$
r_{x y}=\frac{\mathrm{n} \sum \mathrm{XY}-\left(\sum \mathrm{X}\right)\left(\sum \mathrm{X}\right)}{\sqrt{\left\{\mathrm{n} \sum \mathrm{X}^{2}-\left(\sum \mathrm{X}\right)^{2}\right\}\left\{\mathrm{n} \sum \mathrm{Y}^{2}-\left(\sum \mathrm{Y}\right)^{2}\right\}}}
$$

Where:

$\begin{array}{ll}\mathrm{r}_{\mathrm{xy}} & : \text { Correlation coefficient } \\ \mathrm{n} & : \text { Number of subject } \\ \sum \mathrm{X} & : \text { Number of test item } \\ \sum \mathrm{Y} & : \text { Total score of test items } \\ \sum \mathrm{XY} & : \text { Multiplication of items score and total score } \\ \sum \mathrm{X}^{2} & : \text { Quadrate of number of test items } \\ \sum \mathrm{Y}^{2} & : \text { Quadrate of total score of test items }\end{array}$

Table 3.2.

R Coefficient Correlation (Validity)

\begin{tabular}{|l|l|}
\hline $\mathbf{r}_{\mathrm{xy}}$ Score & Interpretation \\
\hline $0.80 \mathrm{r}_{\mathrm{xy}} \leq 1.00$ & Very high \\
\hline $0.60 \mathrm{r}_{\mathrm{xy}} \leq 0.80$ & High \\
\hline $0.40 \mathrm{r}_{\mathrm{xy}} \leq 0.60$ & Moderate \\
\hline $0.20 \mathrm{r}_{\mathrm{xy}} \leq 0.40$ & Low \\
\hline $0.00 \mathrm{r}_{\mathrm{xy}} \leq 0.20$ & Very low \\
\hline$\leq 0.00$ & Not valid \\
\hline
\end{tabular}

The result of the analyzed of the validity test was as follow which can be seen in the following summarized table: 
Table 3.3.

The Result of Validity Test

\begin{tabular}{|l|l|l|}
\hline Item Number & Raw Score & Interpretation \\
\hline 58, & $0.80 \mathrm{r}_{\mathrm{xy}} \leq 1.00$ & Very high \\
\hline $13,21,34,54,57$, & $0.60 \mathrm{r}_{\mathrm{xy}} \leq 0.80$ & High \\
\hline $2,6,11,19,25,27,49,51,52,53,55$, & $0.40 \mathrm{r}_{\mathrm{xy}} \leq 0.60$ & Moderate \\
\hline $1,5,12,16,17,20,22,24,26,29,31,45,47,59$ & $0.20 \mathrm{r}_{\mathrm{xy}} \leq 0.40$ & Low \\
\hline $3,4,7,8,10,14,15,18,23,28,30,32,33,35,36$, & $0.00 \mathrm{r}_{\mathrm{xy}} \leq 0.20$ & Very Low \\
\hline $37,38,39,40,41,42,43,44,46,48,50,56,60$, & & Not Valid \\
\hline 9 & $\mathrm{r}_{\mathrm{xy}} \leq 0.00$ & \\
\hline
\end{tabular}

The numbers showed in table 3.3. Under the item indicate that the item is not valid. If there is one question appear where the raw score is $\leq 0.00$. It means that the test is not valid, so the test is discarded. For the interpretation which is very low there are 28 questions where the raw score is $0.00-0.20$, but the test is used for the pre-test and the post test. And for moderate interpretation there are 11 questions. This means that the questions range from not difficult to very difficult so, it is categorized as a moderate test. For the high interpretation the raw score is $0.60-0.80$. There are 5 questions for the valid test. For a very high interpretation there is 1 question that serves as the very high question. All the questions are still used for the pre-test and post-test.

Reliability

Reliability is an important characteristic of a good test. Reliability means the reliable instrument to be used for collecting the data". To measure the reliability of the instrument in this study, the researcher uses a formula below:

$$
r_{11}=\left(\frac{\mathrm{n}}{\mathrm{n}-1}\right)\left(1 \frac{\varepsilon \sigma_{\overline{2}}}{\sigma^{2} \mathrm{t}}\right)
$$

Arikunto (2013) 
Table 3.4.

R Coefficient Correlation (Reliability)

\begin{tabular}{|l|l|}
\hline Amount of $\mathbf{r}_{11}$ & Interpretation \\
\hline $\mathbf{r}_{11} \leq 0.20$ & Very Low \\
\hline $0.20<\mathrm{r}_{11} \leq 0.40$ & Low \\
\hline $0.40<\mathrm{r}_{11} \leq 0.70$ & Moderate \\
\hline $0.70<\mathrm{r}_{11} \leq 0.90$ & High \\
\hline Amount of $\mathbf{r}_{11}$ & Interpretation \\
\hline $0.90<\mathrm{r}_{11} \leq 1.00$ & Very High \\
\hline
\end{tabular}

After analyzing the data using Anates, the researcher found that the reliability of the test is 0,67 . Based on the category above, the reliability of the test is moderate.

Analysis of Difficulties

The level of difficulty of each item was calculated based on the answers of all students who took the test. Calculating the results was interpreted according to the classification of Arikunto (2013). The formula used is:

$$
T K=\frac{B}{N}
$$

Where:

TK : Level difficulty of each test.

B : Total score obtained by the students on the question.

$\mathrm{N}$ : Number of students.

Table 3.5.

Criteria of Difficulty Level

\begin{tabular}{|l|l|}
\hline Index of Difficulty & Difficulty Degree \\
\hline $\mathrm{Tk}=1.00$ & Very Easy Item \\
\hline $0.70<\mathrm{Tk} \leq 1.00$ & Easy Item \\
\hline $0.30<\mathrm{Tk} \leq 0.70$ & Moderate Item \\
\hline $0.00<\mathrm{Tk} \leq 0.30$ & Difficulty Item \\
\hline $\mathrm{Tk}=0.00$ & Very Difficulty Item \\
\hline
\end{tabular}

After analyzing the data from the instrument test using Anates program, each number of the question is described below: 
Table 3.6.

The Result of Difficulty Test

\begin{tabular}{|l|l|l|}
\hline Item Number & $\begin{array}{c}\text { Interpretation Index } \\
\text { of Difficulty }\end{array}$ & Difficulty Degree \\
\hline & $\mathrm{Tk}=1.00$ & Very Easy Item \\
\hline $4,15,18,30,39,43,44,57,58,59,60$ & $0.70<\mathrm{Tk} \leq 1.00$ & Easy Item \\
\hline $\begin{array}{l}1,3,5,7,8,10,12,13,19,21,22,23,25,28,32,3 \\
4,35,37,38,42,45,52,53,54,55,56,\end{array}$ & $0.30<\mathrm{Tk} \leq 0.70$ & Moderate Item \\
\hline Item Number & $\begin{array}{c}\text { Interpretation Index } \\
\text { of Difficulty }\end{array}$ & Difficulty Degree \\
\hline $\begin{array}{l}2,6,11,14,16,17,20,24,26,27,29,31,33,36,4 \\
0,41,46,47,48,49,50,51,\end{array}$ & $\begin{array}{c}0.00<\mathrm{Tk} \leq 0.30 \\
\text { 9, }\end{array}$ & Difficult Item \\
\hline $9 k=0.00$ & Very Difficult Item \\
\hline
\end{tabular}

Table 3.6 shows that the results of difficulty test are 5 categories; very easy item, easy item, moderate item, difficulty item and very difficult item. For the very easy item interpretation there is no question where the index of difficulty is $\mathrm{Tk}=1.00$. It means that the questions are very easy, but the test is used in the pre-test and post-test. For easy item test there are 11 questions where the index of difficulty is $0.70<\mathrm{Tk} \leq 1.00$. it means that the questions are categorized as an easy test. In moderate test where the index of difficulty is $0.30<\mathrm{Tk} \leq$ 0.70 , there are 26 questions. It means that the questions are not very difficult. For the difficulty item where the index of difficulty is $0.00<\mathrm{Tk} \leq 0.30$, there are 22 questions. For the very difficult item there are 1 question where the index of difficulty is $\mathrm{Tk}=0.00$. But the questions are used in pre-test and post-test.

\section{Discrimination Index}

The discrimination index of item is the question ability to distinguish between high ability and low ability. The following formula was used to calculate the item is (Suprapto, 2013):

$$
D P=\frac{-\bar{X}_{A}-\bar{X}_{B}}{S_{M I}}
$$

Where: $D P$ : Item Discrimination

$$
\begin{array}{ll}
\bar{X}_{A} & : \text { The average of top test takers } \\
\bar{X}_{B} & : \text { The average score of bottom test takers } \\
S_{M I} & : \text { Maximum score }
\end{array}
$$

The criteria of discrimination index were shown in table below: 
Table 3.7.

Criteria of Discrimination index

\begin{tabular}{|l|l|}
\hline Discrimination & Interpretation \\
\hline $0.70-1.00$ & Excellence \\
\hline $0.40-0.70$ & Good \\
\hline $0.20-0.40$ & Satisfaction \\
\hline $0.00-0.20$ & Poor \\
\hline$<0.00$ & Very Bad \\
\hline
\end{tabular}

After analyzing the data, the researcher found the result of discrimination of each question. It is shown in the table below:

Table 3.8.

The result of Discrimination Index

\begin{tabular}{|l|l|l|}
\hline Item Number & Interpretation & $\begin{array}{l}\text { Discrimination } \\
\text { Index }\end{array}$ \\
\hline $13,21,34,42,49,53,54,55,58$, & Excellence & $0.70-1.00$ \\
\hline $1,2,6,11,25,27,45,52,57$, & Good & $0.40-0.70$ \\
\hline $5,16,20,22,24,26,29,38,47,51$, & Satisfaction & $0.20-0.40$ \\
\hline $8,9,10,12,14,17,18,19,31,32,33,36,40,41,43$, & Poor & $0.00-0.20$ \\
\hline $46,48,50,59$, & Very Bad & $<0.00$ \\
\hline $3,4,7,15,23,28,30,35,37,39,44,56,60$ & & \\
\hline
\end{tabular}

Table 3.8 shows that the result of discrimination index there are 5 categories; Excellent, Good, Satisfaction, Poor, and Very Bad. For the excellent test there are 9 questions where the discrimination index is $0.70-1.00$. But still in this excellent test the test is used in pre-test and post-test. For Good interpretation index, there are 9 questions where the discrimination index is $0.40-0.70$. For satisfactory interpretation index, there are 10 questions where the discrimination index is $0.20-0.40$. Poor interpretation, there are 19 questions, but the tests are used in pre-test and post-test. For the very bad test there are 13 questions where the discrimination index is $<0.00$.

\section{Recapitulation}

After analyzing the data from the instrument test using Anates program, each number of the question are described below: 
Table 3.9.

Recapitulation

\begin{tabular}{|c|c|c|c|c|}
\hline No & Item Number & Validity & Difficulty Level & Discrimination \\
\hline 1 & 1, & Low & Moderate & Good \\
\hline 2 & $2,6,11$ & Moderate & Difficult & Good \\
\hline 3 & $3,23,28,35,37,56$ & Not valid & Moderate & Very Bad \\
\hline 4 & $4,7,15,30,39,44$ & Not Valid & Easy & Very Bad \\
\hline 5 & 5,22 & Low & Moderate & Satisfaction \\
\hline 6 & $8,10,32$ & Very Low & Moderate & Poor \\
\hline 7 & 9 & Not Valid & Very Difficult & Very Bad \\
\hline 8 & 12 & Low & Moderate & Poor \\
\hline 9 & $13,21,34,54$ & High & Moderate & Excellent \\
\hline 10 & 14,36 & Not Valid & Difficult & Poor \\
\hline 11 & $16,24,26,29,47$ & Low & Difficult & Satisfaction \\
\hline 12 & $17,31,46$ & Low & Difficult & Poor \\
\hline 13 & 18 & Not Valid & Easy & Poor \\
\hline 14 & $19,25,45,52$ & Moderate & Moderate & Good \\
\hline 15 & 20 & Very Low & Difficult & Satisfaction \\
\hline 16 & 27,49 & Moderate & Difficult & Excellent \\
\hline 17 & $33,40,41,48,50$ & Very Low & Difficult & Poor \\
\hline 18 & 38 & Very Low & Moderate & Satisfaction \\
\hline 19 & $42,53,55$ & Moderate & Moderate & Excellent \\
\hline 20 & 43 & Very Low & Easy & Poor \\
\hline 21 & 51 & Moderate & Difficult & Satisfaction \\
\hline 22 & 57 & High & Easy & Good \\
\hline 23 & 58 & Very High & Easy & Excellent \\
\hline 24 & 59 & Low & Easy & Poor \\
\hline 25 & 60 & Very Low & Easy & Poor \\
\hline
\end{tabular}

Based on the table of recapitulation data of instrument above and after discussing it with the advisor, the researcher eliminates 30 items from the instrument because it did not meet the eligibility criteria of validity and the content. The total number of instruments for the pre-test and post-test was 30 items of the number. 
Gain Analysis

Gain calculation is an analysis to determine the increase in reading comprehension ability of students in the control group and the experimental group on the pre-test and post-test (Hake, 1999). Gain calculation used when the researcher found that the result of pre-test between controlled and experimental group was different. The analysis is done by using the formula normalized gain.

$$
<g>=\frac{<\% \text { post }>-<\text { pre }>}{100 \%-<\% \text { pre }>}
$$

(g)

: average normalized gain

$<\%$ pre $>\quad$ : Percentage of mean score pre-test

$<\%$ post $>\quad$ : Percentage of mean score Post Test

Table 3.10.

Clarification of Gain Score

\begin{tabular}{|l|l|}
\hline \multicolumn{1}{|c|}{ Gain Score Value } & \multicolumn{1}{c|}{ Interpretation } \\
\hline $0.00-0.30$ & Low \\
\hline $0.31-0.70$ & Moderate \\
\hline $0.71-0.100$ & High \\
\hline
\end{tabular}

Pre-Test

The pre-test was conducted on September 23, 2014 in two classes; there were 32 students in grade VIIIA as an experimental group and 33 students in grade VIIIB as a control group. The students in grade VIIIA who took the Pre-test only 31 students and one student, was absent because he was sick. The students in grade VIIIB who was participate in pre-test only 31 students and two students were absent because they were sick.

The goal of the test was to measure the students' reading comprehension ability before and after receiving the treatment. The pre-test was consisted of 30 items in the reading test form.

Table 3.11

The Result of Pre-Test

\begin{tabular}{|l|l|l|l|}
\hline $\begin{array}{l}\text { Participant of Experimental } \\
\text { group }\end{array}$ & $\begin{array}{l}\text { Pre-test Score of } \\
\text { Experimental group }\end{array}$ & $\begin{array}{l}\text { Participant of Control } \\
\text { group }\end{array}$ & $\begin{array}{l}\text { Pre-test Score of } \\
\text { Control Group }\end{array}$ \\
\hline 1 & 73 & 1 & 70 \\
\hline 2 & 67 & 2 & 60 \\
\hline 3 & 70 & 3 & 60 \\
\hline 4 & 70 & 4 & 73 \\
\hline 5 & 73 & 5 & 60 \\
\hline
\end{tabular}




\begin{tabular}{|c|c|c|c|}
\hline $\begin{array}{l}\text { Participant of Experimental } \\
\text { group }\end{array}$ & $\begin{array}{l}\text { Pre-test Score of } \\
\text { Experimental group }\end{array}$ & $\begin{array}{l}\text { Participant of Control } \\
\text { group }\end{array}$ & $\begin{array}{l}\text { Pre-test Score of } \\
\text { Control Group }\end{array}$ \\
\hline 6 & 67 & 6 & 67 \\
\hline 7 & 67 & 7 & 70 \\
\hline 8 & 63 & 8 & 67 \\
\hline 9 & 57 & 9 & 83 \\
\hline 10 & 60 & 10 & 67 \\
\hline 11 & 70 & 11 & 67 \\
\hline 12 & 73 & 12 & 73 \\
\hline 13 & 83 & 13 & 67 \\
\hline 14 & 83 & 14 & 70 \\
\hline 15 & 60 & 15 & 67 \\
\hline 16 & 53 & 16 & 67 \\
\hline 17 & 83 & 17 & 63 \\
\hline 18 & 63 & 18 & 67 \\
\hline 19 & 80 & 19 & 67 \\
\hline 20 & 67 & 20 & 67 \\
\hline 21 & 83 & 21 & 60 \\
\hline 22 & 63 & 22 & 73 \\
\hline 23 & 57 & 23 & 67 \\
\hline 24 & 67 & 24 & 70 \\
\hline 25 & 70 & 25 & 67 \\
\hline 26 & 63 & 26 & 73 \\
\hline 27 & 77 & 27 & 67 \\
\hline 28 & 67 & 28 & 63 \\
\hline 29 & 70 & 29 & 67 \\
\hline 30 & 70 & 30 & 77 \\
\hline 31 & 70 & 31 & 73 \\
\hline Sum & 2140,00 & Sum & 2106,67 \\
\hline Mean & 69,03 & Mean & 67,96 \\
\hline Standar deviasi & 8,04 & Standar deviasi & 5,14 \\
\hline
\end{tabular}


Treatment of the Experimental Group

The following are the steps followed while carrying out jigsaw 1 technique:

1. The teacher/researcher divided students into 5-6 persons jigsaw 1 group. The groups should not be diverse in terms of gender and race.

2. The teacher/researcher appointed one student from each group as the leader. Initially, this person should be the most mature (the person should have good character, responsibility and be able to handle controlled) students in the group,

3. The teacher/researcher divided the lesson into 5-6 segments. For example, if you want to ask the students to write a topic, you might divide the topic into stands alone topic on: (a). (a) The Blow Dryer, (b) The Heart, (c) Trees, (d) Green Grass, (e) Taste. Every topic tells something that has relationship with the students' daily life so that the students can easily comprehend the material to be read.

4. The teacher assigned each student one segment to learn, making sure students have direct access only to their segment,

5. The teacher gave the students time to read the topic at least twice and become familiar with the topic.

6. The teacher formed temporary "expert group" by having one student from each jigsaw group join other students assigned to the same segment. Give students in the expert groups' time to discuss the main point of their segment and to rehearse the presentation they will make to their jigsaw group.

7. Brought the student back into their jigsaw groups,

8. Asked each student to present her/his segment to the group and encouraged others in the groups to ask questions for clarification.

9. The teacher floated the group, observed the process, if any group was having trouble, (e.g., a member is dominating or disruptive), make an appropriate intervention. Eventually, it's best for the group leader to handle this task. Leaders can be trained by whispering instruction on how to intervene, until the leader gets the hang of it.

10. At the end of the session, the teacher/researcher gave a quiz on the material so that students quickly come to realize that these sessions are not just fun and game but really count.

\section{Treatment for the Control Group}

The treatment procedures used by the researcher that has been given to the control group is the conventional teaching method, in other words a more traditional teaching methods lead to a lecture where the teaching-learning activities centered on the teacher which is described below.

1. Every meeting the teacher checked on the attendance of the students.

2. The teacher/researcher told the students that they must focus on learning reading comprehension ability. But in the control group no strategy included in Jigsaw 1 was used.

3. In every meeting in learning reading comprehension ability, the teacher/researcher always gave a different lesson plan. Even though the control group did not use any strategy, the teacher saw the student's improvement in learning reading ability. 
4. In the classroom activity, before the lesson ended the teacher and students discussed together what they had learned about the material.

5. The teacher would grade the students individually according to their homework, quizzes.

\section{Post-Test}

The post test was conducted on November 31, 2014 to grade VIIIA, experimental group and grade VIIIB, control group; the students who participated in post-test were 31 students in grade VIIIA and one student was absent because he was sick, and 31 students participated in grade VIIIB and two students was absent because they were sick. There are 62 students that had been tested using the same question as in post-test.

Table 3.12

The Result of Post-Test

\begin{tabular}{|c|c|c|c|}
\hline $\begin{array}{c}\text { Participant of } \\
\text { Experimental group }\end{array}$ & $\begin{array}{c}\text { Score of Experimental } \\
\text { group }\end{array}$ & $\begin{array}{c}\text { Participant of Control } \\
\text { group }\end{array}$ & $\begin{array}{l}\text { Score of Control } \\
\text { Group }\end{array}$ \\
\hline 1 & 80 & 1 & 73 \\
\hline 2 & 77 & 2 & 73 \\
\hline 3 & 73 & 3 & 67 \\
\hline 4 & 80 & 4 & 80 \\
\hline 5 & 83 & 5 & 73 \\
\hline 6 & 77 & 6 & 70 \\
\hline 7 & 90 & 7 & 70 \\
\hline 8 & 73 & 8 & 63 \\
\hline 9 & 73 & 9 & 83 \\
\hline 10 & 77 & 10 & 73 \\
\hline 11 & 77 & 11 & 70 \\
\hline 12 & 80 & 12 & 77 \\
\hline 13 & 90 & 13 & 73 \\
\hline 14 & 93 & 14 & 77 \\
\hline 15 & 70 & 15 & 73 \\
\hline 16 & 67 & 16 & 73 \\
\hline 17 & 87 & 17 & 77 \\
\hline 18 & 73 & 18 & 73 \\
\hline 19 & 87 & 19 & 70 \\
\hline 20 & 73 & 20 & 70 \\
\hline
\end{tabular}




\begin{tabular}{|c|c|c|c|}
\hline $\begin{array}{c}\text { Participant of } \\
\text { Experimental group }\end{array}$ & $\begin{array}{c}\text { Score of Experimental } \\
\text { group }\end{array}$ & $\begin{array}{c}\begin{array}{c}\text { Participant of Control } \\
\text { group }\end{array} \\
\text {. }\end{array}$ & $\begin{array}{l}\text { Score of Control } \\
\text { Group }\end{array}$ \\
\hline 21 & 90 & 21 & 70 \\
\hline 22 & 77 & 22 & 80 \\
\hline 23 & 80 & 23 & 80 \\
\hline 24 & 77 & 24 & 73 \\
\hline 25 & 87 & 25 & 77 \\
\hline 26 & 83 & 26 & 80 \\
\hline 27 & 83 & 27 & 70 \\
\hline 28 & 80 & 28 & 70 \\
\hline 29 & 80 & 29 & 83 \\
\hline 30 & 83 & 30 & 83 \\
\hline 31 & 80 & 31 & 70 \\
\hline Sum & 2480 & Sum & 2297 \\
\hline Mean & 80 & Mean & 74 \\
\hline Standar deviasi & 6,3828474 & Standar deviasi & 4,9970122 \\
\hline
\end{tabular}

\section{Statistical Procedure}

In analyzing data, the researcher asked advice from the statistician. This advice was implemented in analyze the data gathering.

\section{Normality Test}

Uyanto (2009) Stated, the normality test is very important to determine whether the data is normal or not. If it is normal, it represents the population. The formula can be constructed based on Shapiro Wilk as follow:

$$
\mathrm{X}^{2}=\sum \frac{\left(f_{2}+f_{1}\right)^{2}}{f_{n}} \quad \text { (Ruseffendi, 1998) }
$$

Where:

$\mathrm{n}$ : Number of Score or Number of Subject

$\mathrm{f}_{2}$ : Observation frequency

$\mathrm{f}_{1}$ : Expected frequency

\section{Homogeneity Test}

A homogeneity test is a test to discover the variances of two groups is distributed homogeny to one another or not. In this research, both groups have same number of students $\left(n_{1}=n_{2}\right), \sigma_{1}=\sigma_{2}$ (Homogenous) (Suprapto, 2013), the formula of homogeneity test is: 


$$
F=\frac{\text { the largest variances }}{\text { the smallest variance }}
$$

$S_{1}=$ The variance value of experimental group

$S_{2}=$ The variance value of control group

Ho $=$ variance data homogeny

$\mathrm{Ha}=$ variance data is not homogeny

t-test

In this study the researcher used t test to compare the reading comprehension ability of the two groups evaluated in this study. According Arikunto (2006), the first group was taught within jigsaw 1 while the second groups was taught using the conventional method where the teacher/researcher dominates in the teaching reading process. Following is the formula used to analyze data from these two different samples to find out the effectiveness of the teaching method. To the result of this research, the writer uses $t_{\text {test }}$ formula for the number of respondents in the experimental and control groups. The formula is as follows:

$$
t=\frac{\overline{\mathrm{X}}_{1}-\overline{\mathrm{X}}_{2}}{\sqrt[\mathrm{s}]{\frac{1}{\mathrm{n}_{1}}+\frac{1}{\mathrm{n}_{2}}}}
$$

(Supranto, 2009)

Criteria of Rejecting $\mathrm{H}_{\mathrm{o}}$

If, $\mathrm{Sig} \leq \alpha$ then $\mathrm{H}_{\mathrm{o}}$ is rejected, this means that there is a significant difference in scores between the control group and the experimental group.

If, $\mathrm{Sig} \geq \alpha$ then $\mathrm{H}_{\mathrm{a}}$ is not rejected, there is no significant difference in scores between the control and experimental groups.

In this research, the researcher use $\alpha=5 \%$

\section{Criteria of Normality}

Data sample is normally distributed if $p$ Value (Sig.) is larger than or equal $\alpha=.050$.

Table 4.1

Tests of Normality

\begin{tabular}{|ll|l|l|l|}
\hline \multirow{2}{*}{ Class } & \multicolumn{2}{l}{ Shapiro-Wilk } \\
\cline { 3 - 5 } & Statistic & Df & Sig. \\
\hline Gain-score & $\begin{array}{l}\text { experimental group } \\
\text { control group }\end{array}$ & .941 & 31 & .090 \\
\cline { 2 - 5 } & .946 & 31 & .123 \\
\hline
\end{tabular}

From the table 4.1 Shows that the $p$ Value was sig .090. It means that the data two groups, base Jigsaw 1 technique class and conventional method class were normally distributed. 
Homogeneity Test

The criteria and hypothesis for homogeneity was described as follows:

Homogeneity Criteria

Data sample is homogenous if $p$ Value (Sig.) $\geq \alpha=.050$

\begin{tabular}{|l|l|l|l|l|l|}
\hline \multicolumn{7}{|c|}{ Table 4.2 } \\
Test of Homogeneity of Variances \\
\hline & Levene Statistic & df1 & df2 & Sig. \\
\hline Gain & Based on Mean & .171 & 1 & 60 & .681 \\
\hline
\end{tabular}

Based on the statistics, if the data was normally distributed, then for the homogeneity test, the data was based on Mean. (see table 4.2)

\section{Independent t-Test}

This part was the last factor or formula for calculating the data. The reason the researcher used the independent t-test was because the data and the respondents between the two groups were not dependent on each other. As Uyanto (2012) stated the implementation of the cooperative learning jigsaw technique in the teaching learning process can make the students more responsible. Therefore, they directly and actively take part in addressing a problem and solving it together in a group. And the reason the researcher calculated the t-test was to discover the improvement between the conventional method group and the Jigsaw 1 method group for the post- test after giving the treatment. The criteria and hypothesis for the ttest is described as follow:

\section{Criteria of t-Test}

If, $\mathrm{p}$ Value (Sig.) $\leq \alpha(.050), \mathrm{H}_{\mathrm{a}}$ is accepted and $\mathrm{H}_{\mathrm{o}}$ is rejected, it means there is a significant difference utilizing jigsaw 1 toward improving students' reading comprehension ability.

If, $p$ Value (Sig.) $\geq \alpha(.050), H_{a}$ is rejected and $H_{o}$ is accepted, it means there is no significant difference when utilizing Jigsaw 1 toward improving students' reading comprehension ability.

Hypothesis of the t-test:

Ho: There is no significant difference in reading comprehension ability between those who were taught Jigsaw 1 technique and those who were taught conventional technique. 
Ha: There is a significant difference in reading comprehension ability between those who were taught jigsaw 1 technique and those who were taught conventional technique.

Table 4.3

Independent Samples Test

\begin{tabular}{|c|c|c|c|c|c|c|c|c|c|c|}
\hline & \multicolumn{2}{|c|}{$\begin{array}{l}\text { Levene's Test } \\
\text { for Equality of } \\
\text { Variances }\end{array}$} & \multicolumn{7}{|c|}{ t-test for Equality of Means } \\
\hline & & \multirow[t]{2}{*}{ F } & \multirow[t]{2}{*}{ Sig. } & \multirow[t]{2}{*}{$\mathrm{T}$} & \multirow[t]{2}{*}{ Df } & \multirow[t]{2}{*}{$\begin{array}{l}\text { Sig. (2- } \\
\text { tailed) }\end{array}$} & \multirow[t]{2}{*}{$\begin{array}{l}\text { Mean } \\
\text { Difference }\end{array}$} & \multirow[t]{2}{*}{$\begin{array}{l}\text { Std. } \quad \text { Error } \\
\text { Difference }\end{array}$} & \multicolumn{2}{|c|}{$\begin{array}{l}95 \% \text { Confidence } \\
\text { Interval of the } \\
\text { Difference }\end{array}$} \\
\hline & & & & & & & & & Lower & Upper \\
\hline Gain & $\begin{array}{ll}\text { Equal variances } \\
\text { assumed }\end{array}$ & .171 & .681 & 4.763 & 60 & .000 & .15581 & .03271 & .09037 & .22124 \\
\hline & $\begin{array}{l}\text { Equal variances not } \\
\text { assumed }\end{array}$ & & & 4.763 & 59.984 & .000 & .15581 & .03271 & .09037 & .22124 \\
\hline
\end{tabular}

Therefore, as explained in Table $4.3 \mathrm{Sig} .(.000) \leq \alpha(.050)$. It means that there is significant different in reading comprehension ability for the students who were taught using Jigsaw 1 technique. From the table 4.3 the researcher found the result from Independent samples test, it means that Jigsaw 1 technique on students' reading comprehension ability gave significant effect. And this also can be used as an alternative strategy of teaching reading comprehension ability. Clarke (1994) stated that Jigsaw approach may help build a classroom as a community of learners where they are all valued.

The Mean score is slightly different between jigsaw 1 technique and the conventional method and the potential in both groups is not too different because most of them are still in the beginning of English level.

\section{Summary}

The title of this research is "The Effect of Using Jigsaw 1 to Improve Student's Reading comprehension Ability" The researcher goal was to answer the following question: "Is there any significance difference in reading comprehension ability between those who are taught the Jigsaw 1 technique and those who are taught a conventional technique"?

The researcher conducted the research in SMP Negeri 3 Parongpong, two classes of grade VIII were taken as the control group and the experimental group. The conventional (control group) method was consisted of 33 students and the Jigsaw 1 technique class (experimental group) consisted of 32 students. Both groups were given the same reading material. However, experimental group class was given additional treatment used the Jigsaw 1 technique. A pre-test was conducted for both groups at the beginning. The research began using only reading comprehension text for both group with difference technique of teaching it, and then the post-test was given after 32 hours meetings. The results show that:

For the conventional method class that consists 33 students, the mean pre-test was 67.96, the mean of the post-test was 74 and the mean gain score was 0.20 , it means that the control group gain is categorized as low. This means that in the conventional method class, 
there was an increase in learning reading comprehension ability but without using the Jigsaw 1 technique.

For the experimental group, it consists 32 students, the mean of the pre-test was 69.03 and the mean of the post-test was 80.00 and the mean gain score was 0.35 , it means that the experimental group gain is moderate. This shows that there was an increase of score supported by using the Jigsaw 1 technique in learning reading comprehension ability.

To answer the research question, the researcher focused on the performance of the experimental group. According to statistics, it is shown that there is a difference in the scores of the pre and post test. In the pre-test the researcher did not give any treatment towards students' reading comprehension ability while prior to the post-test for the experimental group the researcher used the Jigsaw 1 technique to achieve the students' reading comprehension ability. And the result was significant as shown in Table 4.3 that Sig. $(.000) \leq$ $\alpha(.050)$. It means that using this method results in a significant different and it is effective to use Jigsaw 1 technique in improving reading comprehension

\section{Conclusion}

In answer to the research question, the researcher has concluded that using the Jigsaw 1 method can significantly improve students' reading comprehension ability. As Uyanto (2012) stated the implementation of the cooperative learning jigsaw technique in the teaching learning process can make the students more responsible. Therefore, they directly and actively take part in addressing a problem and solving it together in a group. This means that the jigsaw 1 technique is one of the good ways for teaching reading in order that the student could comprehend what they read.

\section{Reference}

Aarts, Bas (2008). English Syntax and argumentation, $3^{\text {rd }}$ edn. Basingstoke: Palgrave Macmilan.

Anonymous (2011). The Effectiveness Of Jigsaw Technique In Teaching Reading Towards Students' Reading Skills. Mathla'ul Anwar University Banten

Baker J. Thomas (2012), Teaching English Language Learners Worldwide. Theory \& Praticical Guide. New York. bukukita.com Gramedia

Bolukbas, F., Keskin, F., \&Polat, M. (2011). The effectiveness of cooperative learning in the reading comprehension skills in Turkish as a foreign language. The Turkish Online Journal of EducationalTechnology, 10(4), 330-335.

Ceyhun. O, (2009). The effect of the Jigsaw 1 Technique Implementation on prospective Teachers' Academic Achievements, Public University in Turkey

Edmonds, M. \& Vaughn, S. (2006). Reading Comprehension for Older Reader. Intervention in School and Clinic, 41(3), 131-137.

Fuchs, L.S. et al (2001). Oral Reading Fluency as an indicator of Reading Competence: A theoretical, empirical, and historical analysis. Scientific Studies of Reading, 5, 239-256.

Guthrie, J.T. (2008). Reading Motivation and Engagement in Middle and High School. In J. T. Guthrie (Ed), Engaging adolescent in reading (pp. 1-16). Thousand Oaks, CA: Corwin Press.

Johnson, D. W., Johnson, R. T. (2002). Cooperative learning methods: A meta-analysis. Journal of Research in Education, 12(1), 5-24. 
Mauludi Y.M (2011). The Effectiveness of Jigsaw Technique To Improve Students' Reading Ability In Narrative Text. Walisongo State Institute for Islamic Studies, Semarang.

Mengduo and Xioaling, (2010). Chinese Journal of Applied Linguistics: A Cooperative Learning Technique, Focusing on the Language Learners.

Novianto B. (2012). Improving Reading Comprehension Skills by Using Jigsaw Technique. Kalasan Yogyakarta.

Richard, Jack C., and Renandya, Willy A. (2002). Methodology in Language Teaching. New York: Cambridge University Press.

Slavin, R.E. (2004). Cooperative learning and students' achievement. Educational Leadership, 46:3. S.31-33.

Stevens, J. R. (2003). Student team reading and writing: A cooperative learning approach to middle school literacy instruction, Educational Research and Evaluation. 9, 2, 137-160.

Suprijono, A. 2009. Cooperative Learrning. Yogyakarta: Pustaka pelajar. Nurcahyanti.D, (2013). The Implementation Of Jigsaw Method To Improve Students' Reading Comprehension At The Eighth Grade Of Smp Negeri 2 Jetis Ponorogo 2013 Academic Year.

Webb. N., \& Culian. L.K, (1994). Group Interaction and Achievement in Small Group: Suitability over time, American Education Research Journal, 20(3), 389-397. 